\title{
Evaluating Potential Benefits of Welfare Packages for Development-Induced Involuntary Resettlement in Bangladesh
}

\author{
Miah Md. Tofail ${ }^{1} \&$ Naoko Kaida ${ }^{2}$ \\ ${ }^{1}$ Graduate School of Life and Environmental Sciences, the University of Tsukuba, Tsukuba, Japan \\ ${ }^{2}$ Faculty of Engineering, Information and Systems, the University of Tsukuba, Tsukuba, Japan \\ Correspondence: Naoko Kaida, Faculty of Engineering, Information and Systems, the University of Tsukuba, \\ Tennodai 1-1-1, Tsukuba, Ibaraki, 3058573, Japan. Tel: 81-29-853-5097. E-mail: naoko.kaida@sk.tsukuba.ac.jp
}

\author{
Received: December 10, 2014 Accepted: December 24, $2014 \quad$ Online Published: January 29, 2015 \\ doi: $10.5539 /$ jsd.v8n1p203 \\ URL: http://dx.doi.org/10.5539/jsd.v8n1p203
}

\begin{abstract}
The present study proposes welfare packages to be implemented as part of comprehensive compensation packages to mitigate the long-term socio-economic impacts of development-induced involuntary resettlement and to evaluate potential costs and benefits of the proposed welfare packages. Interviews using structured questionnaires surveyed randomly selected households affected by involuntary resettlement due to land acquisition for the Road Network Improvement and Maintenance Project II (RNIMP-II) in Chittagong-Dohazari area, Bangladesh to gather data on compensation status in the current compensation scheme, willingness to pay (WTP) for and satisfaction with the proposed welfare packages consisting of houses, skill training, health care, and education support. Results of cost-benefit analysis based on estimated WTP as a unit benefit value $(n=205)$ revealed that welfare packages in development-induced involuntary resettlement are economically viable and enhance satisfaction among affected people. The present study also shows that affected people have diverse attitudes in the evaluation of merits expected from welfare packages depending on socio-demographic characteristics such as education, number of children, income, and land ownership and perception of involuntary resettlement operations. These suggest that welfare packages contribute to enhancing quality of life and satisfaction among affected people by involuntary resettlement in the long run, and thus comprehensive compensation packages including welfare packages should be utilized for future development projects that involve involuntary resettlement.
\end{abstract}

Keywords: involuntary resettlement, infrastructure development project, compensation, satisfaction, willingness to pay, contingent valuation, cost-benefit analysis, Bangladesh

\section{Introduction}

Acquisition of private land by governments is commonly seen in infrastructure development for the construction of new highways, dams and so on. This has been increasingly the case in developing countries which face growing demands for transportation networks, water and energy supply as a result of drastic economic and population growth. On the other hand, land acquisition has caused various social problems and surge conflicts between governments and local people who are forced to leave their lands for specific compensation (Asian Development Bank [ADB], 2006). It is estimated that 250-300 million people have been displaced over the last 20 years due to infrastructure development projects and left without effective livelihood restoration activities and thus faced marginalization (Modi, 2009). Involuntary resettlements associated with such development are now recognized as creating serious social, economic, ethical and political problems in many countries. International society has therefore become highly concerned with the issues of development-induced involuntary resettlement (ADB, 2006; World Bank, 2001).

International donors such as the World Bank and the Asian Development Bank (ADB) have set guidelines that require involuntary resettlement operations to provide financial compensation packages to restore not only the loss of land and assets but also livelihoods of affected people to maintain their income levels (ADB, 2006; World Bank, 2001). These guidelines by donors generally require development agencies in recipient countries to comply with the guideline specifications (ADB, 1998).

As in many other developing countries, the issue of development-induced involuntary resettlement is a growing 
concern in Bangladesh where development pressures are increasing and the land scarcity is severe. Infrastructure development projects in Bangladesh have affected approximately 7,000 hectares and 500,000 people between 1994-2004 (Khatun, 2009). Currently, all development-induced involuntary resettlement in donor-funded development projects in Bangladesh comply with donor operational guidelines. Also, the Government of Bangladesh (GOB) has promulgated two laws which set out general matters of land acquisition and practical acts to detail conditions specific to infrastructure development projects such as the Jamuna Multi-Purpose Bridge Project (JMBP) Land Acquisition Act in 1995 and the Act for Land Acquisition of Padma Multipurpose Bridge Project in 2009. Land acquisition and relocation is compensated predominantly by money, specified as cash compensation by law (CCL). However, current financial compensation packages do not satisfy the compensation demands of affected people nor are quality of life restoration programs implemented sufficiently. Protests have occurred by landowners and residents in planned development project sites against land acquisition, including a recent case during the construction of Barisal Marine Academy (Barisal Correspondent, 2013). Since the country is expected to implement a number of development projects to satisfy growing development needs for highways and dams, proper design and implementation of involuntary resettlement associated with development projects is essential to achieve economically and socially sustainable development.

Affected people who are financially compensated for their land and asset loss still face a range of impoverishment risks after relocation such as landlessness, homelessness, joblessness, marginalization, increased morbidity, food insecurity, loss of access to common property resources, and social disarticulation (Cernea, 2003). To minimize such risks, involuntary resettlement should be implemented as a comprehensive package by combining "restoring" and "improving" components of quality of life to support affected people's lives in the long run rather than merely financially compensate immediate losses (Cernea, 2003; Khatun, 2009; Zaman, 1996). That is, involuntary resettlement per se should be treated as a development project to improve livelihoods of affected people after relocation (Cernea, 1997). The concept of resettlement with development that promotes involuntary resettlement operations not only compensates loss but also benefits affected people and has been widely accepted among development donors and alliances (World Commision on Dams, 2000). Yet, in many development projects in developing countries, affected people are still left marginalized after relocation. Momtaz and Kabir (2013) critically evaluated the socio-economic impacts of displacement due to land acquisition for the JMBP project (1993-1998) in Bangladesh and recommended mitigation measures for resettlement that provide planned towns for affected people and income generation training to supplement their livelihood loss (Momtaz \& Kabir, 2013). It has been reported that affected people in many involuntary resettlement cases claim dissatisfaction with their decreased quality of life as well as insufficient financial compensation (ADB, 2008a, 2008b, 2008c). These findings suggest that it is important to carefully design compensation and welfare packages to mitigate impoverishment risks and facilitate satisfaction among affected people during and after the relocation and compensation procedures.

While the importance of sustaining and enhancing quality of life and satisfaction of affected people in involuntary resettlement have been widely recognized (Cernea, 1997), many development projects are still dominated by financial compensation for losses and lack comprehensive compensation efforts by development agencies. One reason for this is that components and social benefits of comprehensive compensation packages in involuntary resettlement are unknown in many projects. Involuntary resettlement operations should be carefully evaluated for their social benefits as well as costs in accordance with operation scope and should be designed as development projects to benefit affected people (Cernea, 1997, 1999a, 1999b, 2003). This is particularly important to facilitate cost-benefit analysis of involuntary resettlement and thus proactive consideration of different resettlement scheme options. Cost-benefit analysis has been performed for development projects that include land acquisition and relocation, but it is not applied to involuntary resettlement operations per se. A comparative field survey on socio-economic changes before and after dam development in China revealed that efforts with resettlement within development through economic incentives and social considerations enhanced income levels and social feelings in a certain county of the affected areas (McDonald, Webber, \& Yuefang, 2008). Another survey on agricultural villages affected by dam development in China revealed that income levels increased after resettlement mainly due to non-agricultural sources (Webber \& McDonald, 2004). This study also pointed out that enhanced incomes were expected to fall after the completion of the project-related construction work, as they were major income sources after relocation. This suggests that resettlement operations must be designed based on the long-term sustainability of affected communities. These studies, however, only evaluate benefits (increased income levels, etc.) of involuntary resettlement implemented in particular development projects. Long-term cost-benefit analysis is essential to validate the viability of comprehensive compensation packages with welfare packages and sustainability of livelihoods and communities of affected people after relocation. 
The present study aimed to propose comprehensive compensation packages that minimize the socio-economic impacts and enhance well-being of people affected in development-induced involuntary resettlement and to examine the viability and social acceptance of the proposed packages. The present study focused on social benefits of the welfare component of comprehensive compensation packages compared with its cost as well as perceived satisfaction among affected people. In the present study, comprehensive compensation packages refer to combined packages of financial compensation for losses and wide ranging welfare packages that cover key social, economic and mental aspects of resettlement. The present study hypothesized that welfare packages included in comprehensive compensation packages will produce greater social benefits than costs and also enhance satisfaction among affected people even if financial compensation is reduced accordingly.

\section{Method}

\subsection{Study Site and Respondents}

The development project investigated in the present study is the Road Network Improvement and Maintenance Project II (RNIMP-II) in Bangladesh. The purpose of this project was to improve the connectivity of national, regional, and Zila (district) roads in the districts of Mymensingh, Kishoregonj, Panchagar, Nilphamari, Dinajpur, and Chittagong by constructing, rehabilitating, and improving road networks (ADB, 2003). The total length of road covered in this project comprised $212.7 \mathrm{~km}$, which were separated into four contracts (No.1-4). RNIMP-II was formulated and financed by ADB and GOB. The project was approved by ADB in 2003 and loan effective starting 2004 with a completion date of 2008. The total funding of the project was US\$121,273,000, with loan breakdowns of US\$ 60,173,000 financed by ADB and the rest locally funded by GOB (ADB, 2014b).

RNIMP-II was one of the recent major infrastructure development projects in the country that involved land acquisition and relocation. The development agency, the Roads and Highways Department (RHD) of GOB Ministry of Communications, initially estimated that the project would require about 186 hectares of land affecting a total of 4,650 households. At the loan project completion in 2013, the land acquisition impact was scaled up to 242 hectares and 19,166 people (ADB, 2014a) due to extension of the project scope. Delays in the overall project were incurred due to increased land acquisition, substantial delays in key decision making by RHD on local consulting works procurement related to land acquisition, and lengthy procedures at the Ministry of Communications and other government agencies, which resulted in extending the close of loan to 2013 initially planned for 2008 (ADB, 2014a).

The target site of the present study was the project area of contract No. 4 responsible for the construction of $26.20 \mathrm{~km}$ of national highway between Chittagong and Dohazari. Contract No. 4 required 58.60 hectares of land acquisition and relocation of 789 households (5,164 people, average household size: 6.54 persons) for the road construction (Ministry of Communications Roads and Highways Department, 2008).

The target respondents in the present survey were heads of project affected households in RNIMP-II in Patiya, Chittagong. All of the respondents were entitled persons (EPs) to receive compensation from the government. Data were collected through interviews using structured questionnaires during January 2014. Two hundred sixteen households were randomly selected from the registered list of EPs. The same number of responses was collected and, as a result of omitting samples with missing values, 205 useable samples were used for analysis. The survey protocol of the present study was approved by the Ethics Committee of the University of Tsukuba.

Table 1 shows the socio-demographic characteristics of the respondents in the present study. The average age of the respondents was 43.88 years old (SD: 12.50). Respondents were predominantly male $(96.76 \%)$ due to the rationale of the questionnaire survey protocol (we approached house heads of the randomly selected households). The average household size was 7.28 persons (SD: 3.88) with an average number of children of 2.16 persons (SD: 1.71$)$. Just over a quarter of respondents $(26.85 \%)$ had attained 12 years or more of education. About three-fourth (73.15\%) of the respondents were self-employed or managed their own business while only $5.56 \%$ engaged in agriculture. The rest of the respondents were either employed in the service sector or laboring work, students or housekeepers. The average annual income level was BDT 141,666 (SD: 84,701) (1 BDT = 0.012 US\$). Respondents' families had lived in the current location for about 45 years on average (SD: 15.41). The majority of respondents $(67.13 \%)$ owned homesteads to be acquired for the project. The average land size acquired for the project per household was 10.34 decimals (SD: 10.15 , approximately $404.60 \mathrm{~m}^{2}$ ). Large standard deviation and the largest land size reported (72 decimals) indicate that there is a large disparity in the land sizes between households acquired for the project. This leads to diverse amounts of compensation received for land loss with an average amount of BDT 327,984 (SD: 546,381). 
Table 1. Socio-demographic characteristics of respondents $(n=205)$

\begin{tabular}{|c|c|c|c|c|c|c|}
\hline & & & Mean, \% & SD & Min & Max \\
\hline Age & AGE & years old & 43.88 & 12.50 & 18 & 70 \\
\hline Gender ( $\%$ of male) & - & $\%$ & 96.76 & & & \\
\hline Household size & HOUSEHOLD & persons & 7.28 & 3.88 & 1 & 26 \\
\hline $\begin{array}{l}\text { Number of children in } \\
\text { household }\end{array}$ & CHILDREN & persons & 2.16 & 1.71 & 0 & 8 \\
\hline $\begin{array}{l}\text { Education ( } \% \text { of schooling } \\
12 \text { years or more) }\end{array}$ & EDU & $\%$ & 26.85 & & & \\
\hline Livelihood & - & $\%$ & & & & \\
\hline Self-employed (including $b$ & ousiness owner) & & 73.15 & & & \\
\hline Farmer & & & 5.56 & & & \\
\hline Employed, service & & & 10.19 & & & \\
\hline Employed, laboring work & & & 6.48 & & & \\
\hline Student & & & 1.39 & & & \\
\hline Housekeeping & & & 3.24 & & & \\
\hline $\begin{array}{l}\text { Income (annual household } \\
\text { income in BDT) }\end{array}$ & INCOME & BDT & 141,666 & 84,701 & $<50,000$ & $>600,000$ \\
\hline $\begin{array}{l}\text { Length of residing the } \\
\text { current location }\end{array}$ & YEARS & years & 45.46 & 15.41 & 19 & 96 \\
\hline $\begin{array}{l}\text { Homestead ownership } \\
\text { (\% of ratio of ownership) }\end{array}$ & OWNERSHIP & $\%$ & 67.13 & & & \\
\hline $\begin{array}{l}\text { Land size to be acquired } \\
\text { for the project } \\
\text { (per household) }\end{array}$ & - & decimals & 10.34 & 10.15 & 1 & 72 \\
\hline $\begin{array}{l}\text { Status of compensation } \\
\text { receipt (\% of household } \\
\text { that had received } \\
\text { compensation at the time } \\
\text { of survey) }\end{array}$ & - & $\%$ & 83 & & & \\
\hline $\begin{array}{l}\text { Amount of compensation } \\
\text { received (per household) }\end{array}$ & - & BDT & 327,984 & 546,381 & 5,000 & $4,374,131$ \\
\hline
\end{tabular}

Note. Approximately $1 \mathrm{BDT}=0.012$ US\$.

\subsection{Proposing Comprehensive Compensation Packages}

In the survey, the present study proposed comprehensive compensation packages as a hypothetical alternative to the current scheme of financial compensation. A comparative summary of the current scheme and the comprehensive compensation packages are shown in Figure 1. The current compensation scheme in RNIMP-II represents financial compensation packages as specified in the Resettlement Action Plan of RNIMP-II (Ministry of Communications Roads and Highways Department, 2008). It consists of 17 components: financial compensation for land and asset losses including common properties, relocation costs, loss of economic opportunities, loss of utility access, additional grants to vulnerable households (e.g., female-headed households), and financial support for skill training. Land acquisition in this contract was estimated to require BDT 342.25 million (US\$ 4.14 million) to cover these compensation components (Ministry of Communications Roads and Highways Department, 2008). 
The comprehensive compensation packages proposed in the present study consist of two major parts, namely, financial compensation and social welfare support. The financial compensation part is equivalent to the current scheme of RNIMP-II since compensation for property losses is essential and significant. The social welfare part is designed to provide holistic and long-term support to project affected households and consists of four major components. The first component of the welfare package is neighborhood- and community- scale relocation to houses with access to water, gas, and electricity utilities. This component is included because relocation to well-planned communities with housing structures would play an important role in sustaining the quality of life of affected households, according to the lessons from previous involuntary resettlement operations in Bangladesh (Momtaz \& Kabir, 2013), Laos (Souksavath \& Nakayama, 2013) and other countries. This support enables affected households to relocate with their families and relatives with whom they had lived in the original neighborhoods prior to relocation. The second component, skill training programs for income restoration, explicitly represents non-cash but substantial support for skill development for alternative livelihoods instead of provision of financial support for training. This is in line with many reports and surveys which suggest that logistic and substantial supports for income restoration is one of the essential but still lacking factors to mitigate socio-economic impacts of involuntary resettlement (ADB, 2008a, 2008b, 2008c; Khatun, 2009; Momtaz \& Kabir, 2013; Sunardi, Gunawan, Manatunge, \& Pratiwi, 2013). In the questionnaire, livelihood skills to be acquired through training were specified as poultry, handicrafts, fishery, and cattle rearing which were reasonable and feasible in the survey area, for better understanding and acceptance by the respondents. The third and fourth components of the proposed welfare packages are health care and education. In his discussion of impoverishment risks associated with involuntary resettlement, Cernea emphasized that health care and education among others should be included in long-term support for affected people as these issues and economic recovery are interdependent and vital to minimize socio-economic impacts of resettlement (Cernea, 1997). Empirical studies also indicate that health and education status of affected people could be vulnerable to the changes in living conditions after resettlement (Dickinson \& Webber, 2007; Tilt, Braun, \& He, 2009; Webber $\&$ McDonald, 2004). The comprehensive compensation packages with welfare packages were presented in a written questionnaire with several pictures to aid respondent's understanding. To avoid any misunderstanding or unnecessary expectations among the respondents, a clear statement was attached indicating that comprehensive compensation packages presented in the survey were hypothetically designed to ascertain respondent's perceptions based on the current compensation conditions.

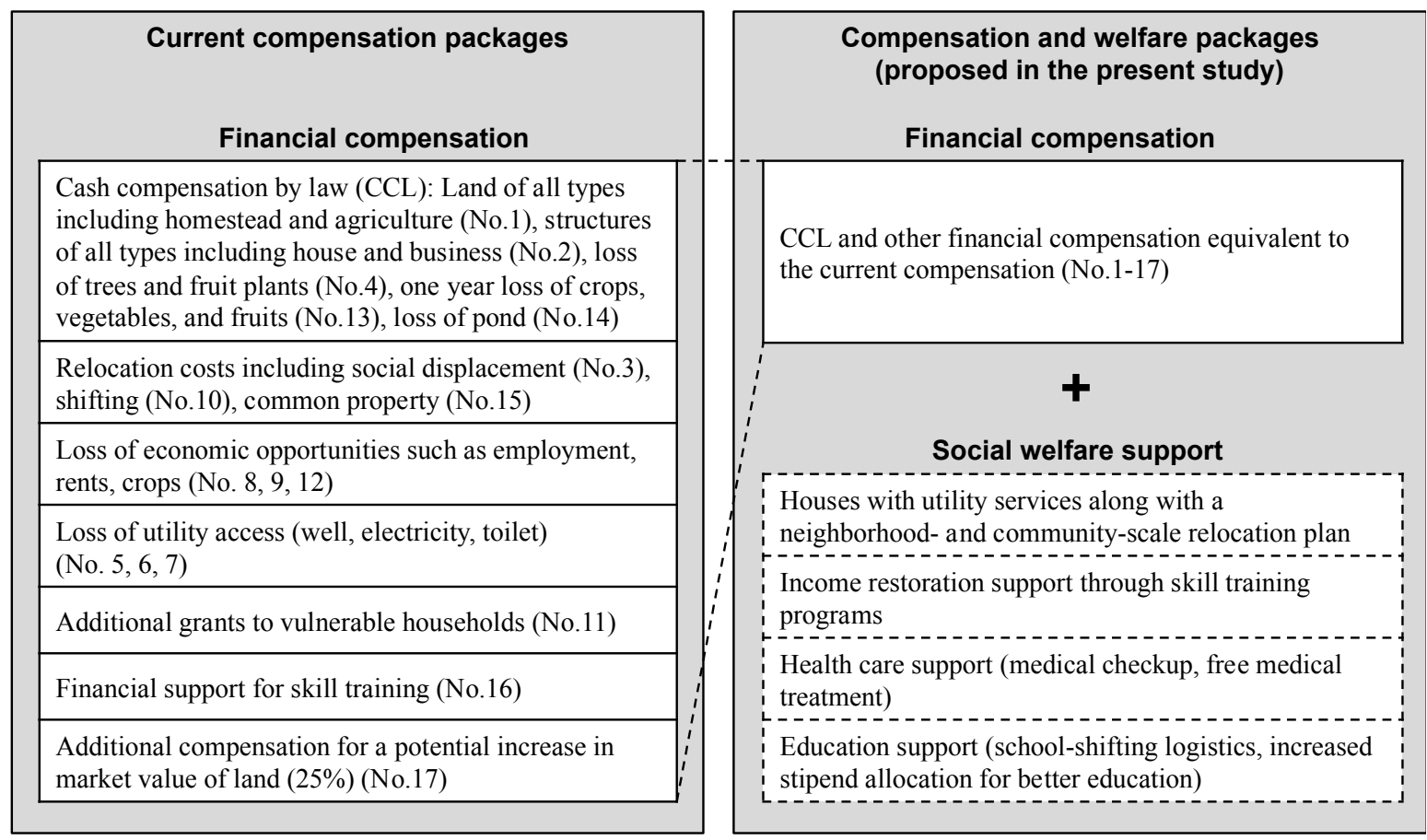

Figure 1. Summary of the compensation packages (in the current scheme and proposed in the present study)

Note. Numbers in the figures indicate serial numbers (No. 1-17) of compensation components specified in the entitlement matrix in the Final Resettlement Action Plan of RNIMP-II (Ministry of Communications Roads and Highways Department, 2008). 


\subsection{Data}

The questionnaire consists of four sections, three of which were used for the analysis in the present study. The questionnaire was provided in Bengali to the respondents.

\subsubsection{Current Status Associated with Land Acquisition and Compensation}

Respondents were asked to provide information of current status for financial compensation and its procedures including the size of land to be acquired, amount of compensation to be paid and procedural stages (whether or not the cash compensation had been already paid). The survey also asked respondents about their evaluation of the current compensation scheme in two ways: whether the total amount of compensation approved by the development agency was sufficient, and whether the respondents had to wait a long time to receive cash compensation. The former question was to determine an affected household's subjective assessment of financial compensation by the development agency, and the latter was to determine their trust in the operational capacity of the development agency. Respondents were also asked their overall satisfaction with the current scheme. Respondents rated their responses using a 7-point Likert scale on their evaluation regarding the amount of compensation ("very insufficient" to "very sufficient"), time required to receive the compensation ("very long" to "very short"), and overall satisfaction ("very dissatisfied" to "very satisfied"), respectively.

\subsubsection{Contingent Valuation Question based on Hypothetical Scenario}

In order to obtain data for the benefit estimation of the proposed welfare packages, respondents were asked their willingness to pay (WTP) based on a hypothetical scenario. The scenario and WTP questions were designed based on the contingent valuation method (CVM). CVM is a direct method for the valuation of non-market products or services and involves asking a selected sample of population regarding their WTP for the provision of a specific service or goods (Mitchell \& Carson, 1989). In the present survey, respondents were given a scenario where they received financial compensation for land and asset losses as approved in the current compensation scheme (baseline condition) however some other social welfare support would be available as additional components in the compensation packages as specified in Figure 1 (positive change from baseline), which would require some additional costs. The respondents were then asked how much they were willing to pay in order to enjoy these additional benefits. WTP was asked as payment per household per month. Respondents were asked to answer a double-bounded dichotomous choice question with either of three different bid sets, namely: BID1 ( $\mathrm{B}_{\mathrm{i}}$ : BDT 5,000, $\mathrm{B}_{\mathrm{u}}$ : BDT 7,000, and $\mathrm{B}_{\mathrm{l}}$ : BDT 2,000), BID2 (B $\mathrm{B}_{\mathrm{i}}$ : BDT 10,000, $\mathrm{B}_{\mathrm{u}}$ : BDT 20,000, and $\mathrm{B}_{1}$ : BDT 5,000), and BID3 ( $\mathrm{B}_{\mathrm{i}}$ : BDT 20,000, $\mathrm{B}_{\mathrm{u}}$ : BDT 30,000, and $\mathrm{B}_{1}$ : BDT 15,000).

\subsubsection{Perceptions of the Proposed Compensation}

Respondents were asked to give their opinions about overall satisfaction with the hypothetical compensation and welfare package explained in the previous section. Another set of questions asked respondents' perceived importance of each welfare component, namely houses for neighborhood- and community-scale relocation, utility services, skill training, health care, and education support. It was explained to the respondents that they would incur some costs under the proposed welfare packages as described in the prior section. Respondents were asked to rate their satisfaction and importance using a 7-point Likert scale ("very dissatisfied" to "very satisfied", "not important at all" to "very important").

\subsection{Analysis}

\subsubsection{WTP Estimation}

The present study estimated WTP to obtain a unit value for benefits of the welfare packages proposed as part of comprehensive compensation packages. Questionnaire data collected about respondents' yes-no choices to bids were entered into the maximum likelihood estimation function to estimate monthly WTP for the welfare packages. Variables related to socio-demographic characteristics, compensation status, and satisfaction and perceived importance about the welfare packages (Table 1 and Table 2) were then entered to the WTP estimation to examine the effects of these factors on respondent's willingness to pay. 
Table 2. Variables used in the analysis $(\mathrm{n}=205)$

\begin{tabular}{|c|c|c|c|}
\hline \multicolumn{2}{|c|}{ Variables related to the current compensation scheme } & Mean & SD \\
\hline SATISFACTION_C & Overall satisfaction ("very dissatisfied" (1) to "very satisfied" (7)) & 1.97 & 1.06 \\
\hline COMPENSATION & $\begin{array}{l}\text { Sufficiency of compensation (sufficiency of the cash compensation } \\
\text { received) ("very insufficient" (1) to "very sufficient" (7)) }\end{array}$ & 1.93 & 0.92 \\
\hline TIME & $\begin{array}{l}\text { Time required to receive compensation (time length required to } \\
\text { receive cash compensation) ("too long" (1) to "very short" (7)) }\end{array}$ & 2.53 & 1.21 \\
\hline \multicolumn{4}{|c|}{ Variables related to the welfare package proposed in the hypothetical compensation scenario } \\
\hline SATISFACTION_P & Overall satisfaction ("very dissatisfied" (1) to "very satisfied" (7)) & 6.17 & 0.71 \\
\hline HOUSE & Houses ("not important at all" (1) to "very important" (7)) & 6.55 & 0.53 \\
\hline UTILITY & Utility services ("not important at all" (1) to "very important" (7)) & 6.82 & 0.40 \\
\hline SKILL & Skill training ("not important at all" (1) to "very important" (7)) & 5.56 & 0.56 \\
\hline HEALTH & Health care ("not important at all" (1) to "very important" (7)) & 6.73 & 0.54 \\
\hline EDU & Education support ("not important at all” (1) to "very important" (7)) & 6.13 & 0.52 \\
\hline
\end{tabular}

\subsubsection{Cost-Benefit Analysis}

For the cost-benefit analysis, the present study assumed that a welfare package project covers all the affected households in the survey area of Chittagong-Dohazari $(n=789)$. The project period was assumed as 30 years, taking into consideration the durability of housing structures and lifetime left of the current generation of affected households. Benefits were estimated using the estimated WTP as a unit value of benefit per household per month. Costs were estimated based on unit values for practical costs of implementing the welfare packages. Unit data for costs were estimated for each component based on reference values obtained from different sources including government documents and general market records (e.g., Patiya Sub Registry Office for land price available for 2014, and Resalah Properties \& Design Technologies for building design and construction). Provision of houses with utilities consisted of land purchase and construction works during the first three years of the welfare package operations. Other components were assumed to start in the first year and run for the entire period. In sum, total annual costs for the first three years and for the rest of the project period were estimated to be BDT 400.48 million and BDT 16.10 million, respectively (Table 3). The present study applied two discount rates, 10\% (Jalil, 2010; Zhuang, Liang, Lin, \& Guzman, 2007) and 3\% (WHO, 2003) for a 30-year cost-benefit comparison, taking into consideration the significant and controversial impacts of rates on the economic viability of long-term public works. All the data preparation and analysis was performed using Stata 12. 
Table 3. Unit values for costs

\begin{tabular}{|c|c|c|c|c|}
\hline \multirow[b]{2}{*}{ Item of works } & \multirow[b]{2}{*}{ Quantity } & \multirow[b]{2}{*}{ Unit } & \multicolumn{2}{|c|}{ (million BDT) } \\
\hline & & & Unit rate & Amount \\
\hline \multicolumn{5}{|l|}{ A. Housing construction ( 3 years) } \\
\hline Land purchase & 396 & decimal & 0.162 & 64.15 \\
\hline \multicolumn{5}{|l|}{ Construction of housing buildings } \\
\hline (66 six-storied building, 2,000 sft each floor and & 66 & unit & 16.500 & $1,089.00$ \\
\hline \multicolumn{5}{|l|}{ 1,000 sft per household, including utilities) } \\
\hline Sub total (A) & & & & $1,153.15$ \\
\hline Sub total annual $(\mathrm{Aa})$ & & & & 384.38 \\
\hline \multicolumn{5}{|l|}{ B. Other components (per year) } \\
\hline Skill training program & 789 & household & 0.006 & 4.73 \\
\hline Health care & 789 & household & 0.008 & 6.63 \\
\hline Education support & 789 & household & 0.006 & 4.73 \\
\hline Sub total (B) & & & & 16.10 \\
\hline Total annual for the first 3 years $(\mathrm{Aa}+\mathrm{B})$ & & & & 400.48 \\
\hline Total annual for the rest of the project period (B) & & & & 16.10 \\
\hline
\end{tabular}

\section{Results}

\subsection{WTP}

Table 4 presents the results of WTP estimation using maximum likelihood. This table shows four different models, Model 1 (with no control variables), Model 2 (with socio-demographic variables), Model 3 (additional variables related to the current compensation scheme), and Model 4 (further additional variables related to the proposed welfare packages). Mean WTP per household per month estimated for the welfare packages proposed in the present study was BDT 8,813.85 (Model 1, approximately US\$ 105.77). Mean WTPs estimated for the four models are within a narrow range of BDT 8801.92 and 8830.38. WTP in Model 1 were used as the unit value for benefits for cost-benefit analysis.

Several socio-demographic characteristics, namely EDU, CHILDREN, INCOME, and OWNERSHIP were found significant and positively related to WTP. HOUSEHOLD was found significant and negative in Model 2 which focused on socio-demographic characteristics of respondents. In regard to variables related to the current compensation scheme, only TIME was found significant and positive (Model 3 and 4). SATISFACTION_C (overall satisfaction for the current scheme) was found to be insignificant. Among the variables related to the proposed welfare packages, only SATISFACTION_P (overall satisfaction) was found significant and positively related to WTP (Model 4). Mean satisfaction score for the proposed comprehensive compensation packages were significantly higher than that for the current scheme (Table 2), and all the respondents provided higher scores for the proposed packages. 
Table 4. WTP estimation results $(\mathrm{n}=205)$

\begin{tabular}{|c|c|c|c|c|}
\hline & Model 1 & Model 2 & Model 3 & Model 4 \\
\hline AGE & & 1.58 & -5.88 & -15.39 \\
\hline EDU & & $428.54^{* *}$ & $399.94^{* *}$ & $375.39^{* *}$ \\
\hline HOUSEHOLD & & $-176.97^{*}$ & -139.47 & -149.25 \\
\hline CHILDREN & & $479.80^{* *}$ & $391.65^{* *}$ & $391.26^{*}$ \\
\hline INCOME & & $0.06^{* * *}$ & $0.06^{* * *}$ & $0.06^{* *}$ \\
\hline YEARS & & 18.97 & 18.59 & 28.07 \\
\hline OWNERSHIP & & $1221.87^{* *}$ & $1524.76^{* * *}$ & $1393.13^{\text {** }}$ \\
\hline SATISFACTION_C & & & 254.87 & 276.82 \\
\hline COMPENSATION & & & -183.79 & -270.89 \\
\hline TIME & & & $450.20^{* * *}$ & $465.61^{* *}$ \\
\hline SATISFACTION_P & & & & $762.11^{* *}$ \\
\hline HOUSE & & & & 195.02 \\
\hline UTILITY & & & & 98.48 \\
\hline SKILL & & & & 717.52 \\
\hline HEALTH & & & & -136.70 \\
\hline EDU_SUPPORT & & & & 82.87 \\
\hline Intercept & $8813.85^{* * *}$ & $-2516.69^{* *}$ & $-3689.16^{* * *}$ & -13457.27 * \\
\hline Mean WTP (BDT) & $8813.85^{* * *}$ & $8807.18^{* * *}$ & $8801.92^{* * *}$ & 8830.38 \\
\hline Log likelihood & -626.96 & -251.36 & -247.89 & -243.41 \\
\hline
\end{tabular}

Note. Significant at $\mathrm{p}<0.1\left(^{*}\right), 0.05\left(^{* *}\right)$, and $0.01\left(^{* * *}\right)$.

\subsection{Benefit and Cost Estimation of the Proposed Welfare Packages}

Benefits associated with the proposed welfare packages were estimated using a mean WTP (BDT 8,813.85) per household per month as the unit benefit value. Assuming that the welfare packages target the entire affected households ( $\mathrm{n}=789$ ), annual benefits were estimated to be BDT 83,449,532.

Table 5 and 6 present the results of cost-benefit analysis on the proposed welfare packages assuming resettlement as a 30-year project and with discount rates of $10 \%$ and $3 \%$. Discounted cumulative costs and benefits with a discount rate of $10 \%$ were BDT 1,107.67 million and BDT 786.68 million respectively, which yielded a $\mathrm{B} / \mathrm{C}$ ratio of 0.71 . In the same way, discounted cumulative costs and benefits with a discount rate of $3 \%$ were BDT 1,402.83 million and BDT 1,635.66 million, respectively. These results yielded a B/C ratio of 1.17. 
Table 5. Cost and benefit estimation results using discount rate of $10 \%$

(million BDT)

\begin{tabular}{cccc}
\hline & $\begin{array}{c}\text { Undiscounted annual } \\
\text { costs and benefits }\end{array}$ & Discount $\begin{array}{c}\text { Discounted annual costs } \\
\text { and benefits }\end{array}$ & $\begin{array}{c}\text { Discounted cumulative } \\
\text { costs and benefits }\end{array}$
\end{tabular} Annual net benefits

$\begin{array}{llllll}\text { (a) Costs } & \text { (b) Benefits factor } & \text { (c) Costs (d) Benefits Costs Benefits } \begin{array}{c}\text { Undiscounted Discounted } \\ \text { (b-a) }\end{array}\end{array}$

\begin{tabular}{|c|c|c|c|c|c|c|c|c|c|}
\hline & & & & & & & & & \\
\hline 1 & 400.48 & 83.45 & 1.10 & 364.07 & 75.86 & 364.07 & 75.86 & -317.03 & -288.21 \\
\hline 2 & 400.48 & 83.45 & 1.21 & 330.98 & 68.97 & 695.05 & 144.83 & -317.03 & -262.01 \\
\hline 3 & 400.48 & 83.45 & 1.33 & 300.89 & 62.70 & 995.93 & 207.53 & -317.03 & -238.19 \\
\hline 4 & 16.10 & 83.45 & 1.46 & 11.00 & 57.00 & $1,006.93$ & 264.53 & 67.35 & 46.00 \\
\hline 5 & 16.10 & 83.45 & 1.61 & 10.00 & 51.82 & $1,016.93$ & 316.34 & 67.35 & 41.82 \\
\hline 6 & 16.10 & 83.45 & 1.77 & 9.09 & 47.11 & $1,026.02$ & 363.45 & 67.35 & 38.02 \\
\hline 7 & 16.10 & 83.45 & 1.95 & 8.26 & 42.82 & $1,034.28$ & 406.27 & 67.35 & 34.56 \\
\hline 8 & 16.10 & 83.45 & 2.14 & 7.51 & 38.93 & $1,041.79$ & 445.20 & 67.35 & 31.42 \\
\hline 9 & 16.10 & 83.45 & 2.36 & 6.83 & 35.39 & $1,048.62$ & 480.59 & 67.35 & 28.56 \\
\hline 10 & 16.10 & 83.45 & 2.59 & 6.21 & 32.17 & $1,054.82$ & 512.76 & 67.35 & 25.97 \\
\hline 11 & 16.10 & 83.45 & 2.85 & 5.64 & 29.25 & $1,060.47$ & 542.01 & 67.35 & 23.61 \\
\hline 12 & 16.10 & 83.45 & 3.14 & 5.13 & 26.59 & $1,065.60$ & 568.60 & 67.35 & 21.46 \\
\hline 13 & 16.10 & 83.45 & 3.45 & 4.66 & 24.17 & $1,070.26$ & 592.78 & 67.35 & 19.51 \\
\hline 14 & 16.10 & 83.45 & 3.80 & 4.24 & 21.97 & $1,074.50$ & 614.75 & 67.35 & 17.74 \\
\hline 15 & 16.10 & 83.45 & 4.18 & 3.85 & 19.98 & $1,078.35$ & 634.73 & 67.35 & 16.12 \\
\hline 16 & 16.10 & 83.45 & 4.59 & 3.50 & 18.16 & $1,081.86$ & 652.89 & 67.35 & 14.66 \\
\hline 17 & 16.10 & 83.45 & 5.05 & 3.19 & 16.51 & $1,085.04$ & 669.40 & 67.35 & 13.32 \\
\hline 18 & 16.10 & 83.45 & 5.56 & 2.90 & 15.01 & $1,087.94$ & 684.41 & 67.35 & 12.11 \\
\hline 19 & 16.10 & 83.45 & 6.12 & 2.63 & 13.64 & $1,090.57$ & 698.05 & 67.35 & 11.01 \\
\hline 20 & 16.10 & 83.45 & 6.73 & 2.39 & 12.40 & $1,092.96$ & 710.46 & 67.35 & 10.01 \\
\hline 21 & 16.10 & 83.45 & 7.40 & 2.18 & 11.28 & $1,095.14$ & 721.73 & 67.35 & 9.10 \\
\hline 22 & 16.10 & 83.45 & 8.14 & 1.98 & 10.25 & $1,097.12$ & 731.99 & 67.35 & 8.27 \\
\hline 23 & 16.10 & 83.45 & 8.95 & 1.80 & 9.32 & $1,098.92$ & 741.30 & 67.35 & 7.52 \\
\hline 24 & 16.10 & 83.45 & 9.85 & 1.63 & 8.47 & $1,100.55$ & 749.78 & 67.35 & 6.84 \\
\hline 25 & 16.10 & 83.45 & 10.83 & 1.49 & 7.70 & $1,102.04$ & 757.48 & 67.35 & 6.22 \\
\hline 26 & 16.10 & 83.45 & 11.92 & 1.35 & 7.00 & $1,103.39$ & 764.48 & 67.35 & 5.65 \\
\hline 27 & 16.10 & 83.45 & 13.11 & 1.23 & 6.37 & $1,104.62$ & 770.85 & 67.35 & 5.14 \\
\hline 28 & 16.10 & 83.45 & 14.42 & 1.12 & 5.79 & $1,105.73$ & 776.63 & 67.35 & 4.67 \\
\hline 29 & 16.10 & 83.45 & 15.86 & 1.01 & 5.26 & $1,106.75$ & 781.89 & 67.35 & 4.25 \\
\hline 30 & 16.10 & 83.45 & 17.45 & 0.92 & 4.78 & $\mathbf{1 , 1 0 7 . 6 7}$ & 786.68 & 67.35 & 3.86 \\
\hline
\end{tabular}


Table 6. Cost and benefit estimation results using discount rate of $3 \%$

(million BDT)

\begin{tabular}{|c|c|c|c|c|c|c|c|c|c|}
\hline \multirow{2}{*}{ Year } & \multicolumn{2}{|c|}{$\begin{array}{l}\text { Undiscounted annual costs } \\
\text { and benefits }\end{array}$} & \multirow{2}{*}{$\begin{array}{c}\text { Discount } \\
\text { factor }\end{array}$} & \multicolumn{2}{|c|}{$\begin{array}{l}\text { Discounted annual costs } \\
\text { and benefits }\end{array}$} & \multicolumn{2}{|c|}{$\begin{array}{l}\text { Discounted cumulative } \\
\text { costs and benefits }\end{array}$} & \multicolumn{2}{|c|}{ Annual net benefits } \\
\hline & (a) Costs & (b) Benefits & & (c) Costs & (d) Benefits & Costs & Benefits & $\begin{array}{l}\text { Undiscounted } \\
\text { (b-a) }\end{array}$ & $\begin{array}{l}\text { Discounted } \\
\text { (d-c) }\end{array}$ \\
\hline 1 & 400.48 & 83.45 & 1.03 & 388.82 & 81.02 & 388.82 & 81.02 & -317.03 & -307.80 \\
\hline 2 & 400.48 & 83.45 & 1.06 & 377.49 & 78.66 & 766.31 & 159.68 & -317.03 & -298.83 \\
\hline 3 & 400.48 & 83.45 & 1.09 & 366.50 & 76.37 & $1,132.80$ & 236.05 & -317.03 & -290.13 \\
\hline 4 & 16.10 & 83.45 & 1.13 & 14.30 & 74.14 & $1,147.11$ & 310.19 & 67.35 & 59.84 \\
\hline 5 & 16.10 & 83.45 & 1.16 & 13.89 & 71.98 & $1,160.99$ & 382.18 & 67.35 & 58.10 \\
\hline 6 & 16.10 & 83.45 & 1.19 & 13.48 & 69.89 & $1,174.48$ & 452.06 & 67.35 & 56.40 \\
\hline 7 & 16.10 & 83.45 & 1.23 & 13.09 & 67.85 & $1,187.57$ & 519.92 & 67.35 & 54.76 \\
\hline 8 & 16.10 & 83.45 & 1.27 & 12.71 & 65.88 & $1,200.28$ & 585.79 & 67.35 & 53.17 \\
\hline 9 & 16.10 & 83.45 & 1.30 & 12.34 & 63.96 & $1,212.62$ & 649.75 & 67.35 & 51.62 \\
\hline 10 & 16.10 & 83.45 & 1.34 & 11.98 & 62.09 & $1,224.60$ & 711.85 & 67.35 & 50.11 \\
\hline 11 & 16.10 & 83.45 & 1.38 & 11.63 & 60.29 & $1,236.23$ & 772.13 & 67.35 & 48.66 \\
\hline 12 & 16.10 & 83.45 & 1.43 & 11.29 & 58.53 & $1,247.52$ & 830.66 & 67.35 & 47.24 \\
\hline 13 & 16.10 & 83.45 & 1.47 & 10.96 & 56.83 & $1,258.48$ & 887.49 & 67.35 & 45.86 \\
\hline 14 & 16.10 & 83.45 & 1.51 & 10.64 & 55.17 & $1,269.13$ & 942.66 & 67.35 & 44.53 \\
\hline 15 & 16.10 & 83.45 & 1.56 & 10.33 & 53.56 & $1,279.46$ & 996.22 & 67.35 & 43.23 \\
\hline 16 & 16.10 & 83.45 & 1.60 & 10.03 & 52.00 & $1,289.50$ & $1,048.22$ & 67.35 & 41.97 \\
\hline 17 & 16.10 & 83.45 & 1.65 & 9.74 & 50.49 & $1,299.24$ & $1,098.71$ & 67.35 & 40.75 \\
\hline 18 & 16.10 & 83.45 & 1.70 & 9.46 & 49.02 & $1,308.69$ & $1,147.73$ & 67.35 & 39.56 \\
\hline 19 & 16.10 & 83.45 & 1.75 & 9.18 & 47.59 & $1,317.87$ & $1,195.32$ & 67.35 & 38.41 \\
\hline 20 & 16.10 & 83.45 & 1.81 & 8.91 & 46.20 & $1,326.79$ & $1,241.53$ & 67.35 & 37.29 \\
\hline 21 & 16.10 & 83.45 & 1.86 & 8.65 & 44.86 & $1,335.44$ & $1,286.38$ & 67.35 & 36.20 \\
\hline 22 & 16.10 & 83.45 & 1.92 & 8.40 & 43.55 & $1,343.85$ & $1,329.94$ & 67.35 & 35.15 \\
\hline 23 & 16.10 & 83.45 & 1.97 & 8.16 & 42.28 & $1,352.00$ & $1,372.22$ & 67.35 & 34.13 \\
\hline 24 & 16.10 & 83.45 & 2.03 & 7.92 & 41.05 & $1,359.92$ & $1,413.27$ & 67.35 & 33.13 \\
\hline 25 & 16.10 & 83.45 & 2.09 & 7.69 & 39.86 & $1,367.61$ & $1,453.13$ & 67.35 & 32.17 \\
\hline 26 & 16.10 & 83.45 & 2.16 & 7.47 & 38.70 & $1,375.08$ & $1,491.82$ & 67.35 & 31.23 \\
\hline 27 & 16.10 & 83.45 & 2.22 & 7.25 & 37.57 & $1,382.33$ & $1,529.39$ & 67.35 & 30.32 \\
\hline 28 & 16.10 & 83.45 & 2.29 & 7.04 & 36.47 & $1,389.36$ & $1,565.86$ & 67.35 & 29.44 \\
\hline 29 & 16.10 & 83.45 & 2.36 & 6.83 & 35.41 & $1,396.20$ & $1,601.28$ & 67.35 & 28.58 \\
\hline 30 & 16.10 & 83.45 & 2.43 & 6.63 & 34.38 & $1,402.83$ & $1,635.66$ & 67.35 & 27.75 \\
\hline
\end{tabular}

\section{Discussion}

The aims of the present study were to propose welfare packages to be implemented along with a financial compensation scheme in development-induced involuntary resettlement in Bangladesh and to evaluate its economic viability using cost-benefit analysis.

A willingness to pay survey based on CVM was performed to obtain unit value data for benefit estimation. Mean WTP estimated based on the survey data is within a reasonable range taking into account the merits proposed in the scenario (houses with utilities, skill training, support for health care and education). Maximum likelihood estimation also revealed that socio-demographic characteristics such as education attainment, number of children, income, and homestead ownership have positive effects on WTP. Results on education and income levels are in line with previous findings from WTP studies using CVM on programs related to welfare and environmental improvement in developing countries. Individuals who have higher education attainment and income level tend to state a stronger preference for positive changes (Dong, Kouyate, Cairns, Mugisha, \& Sauerborn, 2003; Dong, Kouyate, Snow, Mugisha, \& Sauerborn, 2003; Dror, Radermacher, \& Koren, 2007; Kaida \& Dang, 2014). The positive relationship of the number of children in a household to WTP may explain that parents are seriously concerned with the impacts of resettlement on their children's future and households with more children perceive larger merits compared to those with fewer children. The negative effect of household size on WTP obtained in Model 2 suggests that households with a larger number of family members tend to have a lower evaluation of the benefits of positive changes in their welfare status as a result of comparative economic concerns related to their daily lives.

Results of land ownership imply that affected persons who legally own their lands are more concerned with losing their properties and expect alternative merits in the proposed welfare packages. Results of time required to 
receive compensation suggest that affected people who trust the development agency's operational ability with a proper timeframe tend to expect more benefits from potential welfare merits in the proposed packages compared to those who give a lower evaluation of the development agency. Satisfaction with the proposed welfare packages was found to be significant and positive. This result suggests that the positive evaluation of the welfare packages may have contributed to a higher willingness to pay for the merits. Moreover, satisfaction with the proposed welfare packages was found to be significantly higher than with the current scheme, and all the respondents stated a higher satisfaction with the proposals compared to the current scheme. These results imply that conventional financial compensation packages alone do not necessarily contribute to positive evaluation of involuntary resettlement operations.

Cost-benefit analysis results indicate that the $\mathrm{B} / \mathrm{C}$ ratio exceeds 1.0 , assuming a $3 \%$ discount rate for a 30 -year project. This suggests that potential benefits of welfare support to affected people in involuntary resettlement may be larger than its costs and such engagement by development agencies could be economically viable in the long run from a public policy perspective. To the best of our knowledge, potential benefits and economic viability of welfare packages associated with development-induced involuntary resettlement has not been previously reported. Many studies have discussed financial compensation based on CCL or land-to-land compensation for land acquisition due to infrastructure development is not sufficient to fully compensate a diverse range of losses and risks that affected people will face such as livelihood, education opportunities, health, community ties, and social capital (Cernea, 2003; Fujikura \& Nakayama, 2013; Khatun, 2009; Momtaz \& Kabir, 2013; Souksavath \& Nakayama, 2013; Zaman, 1996). For example, Souksavath and Nakayama evaluated impacts of involuntary resettlement and non-cash compensation packages, which included not only housing but also various welfare facilities such as education and medical facilities, on livelihood and satisfaction among affected households (Souksavath \& Nakayama, 2013). They found that affected households were generally satisfied with the resettlement as their income levels and quality of life including children had improved through a series of resettlement operations. However, benefits and costs were not considered in their study. In light of this, the present study presents new results. The present finding of cost-benefit analysis supports the idea of evolving impoverishment risks and reconstruction in involuntary resettlement and designing resettlement operations as a development project (Cernea, 1997, 1999b, 2003). It would also encourage development agencies and international donors to design comprehensive compensation packages with welfare components and to evaluate potential costs and benefits of their plans to justify their economic viability.

A few key limitations of the present research should be noted. First, the scope of the welfare packages examined in the present research may not be comprehensive enough to mitigate the impoverishment risks in involuntary resettlement. Among a range of risks that should be mitigated, the proposed welfare packages only cover housing, livelihood, and health and education issues. Furthermore, detailed designs of each welfare component may have not been elaborated thoroughly. This might be the reason why variables of these four components are not significantly related to the benefit evaluation. Meanwhile, these components received high recognition by respondents (mean values $>6.0$ (important/very important), skill training: 5.56), and also overall satisfaction of the welfare packages is considerably higher than the current scheme that primarily covers financial compensation for economic losses only. The present results thus support the importance of integrating welfare packages into conventional compensation schemes to provide comprehensive support to affected people in involuntary resettlement. Detailed designs and implementation of such comprehensive compensation packages will be investigated in a future study.

Second, viability of the proposed welfare packages evaluated in the present research largely relies on discount rate levels that are applied in cost-benefit analysis. Economic viability supported in the present research may be due to discount rates that are set considerably lower compared to the rates that are used in evaluation studies on development projects in developing countries in recent years. Potential benefits estimated for the welfare package do not exceed the costs when applying a discount rate of $10 \%$. There have been long debates on social discount rate settings in evaluating costs and benefits of development projects. While $8-12 \%$ of discount rates are normally applied in cost-benefit analysis of development projects in developing countries, it has been suggested that projects which produce long-term benefits such as education, welfare, and environment should be evaluated using much lower rates (ADB, 2013; Zhuang et al., 2007). For example, Brandon and Hommann's group and Sen and her colleagues applied a discount rate of $5 \%$ for evaluations of environmental degradation in India and urban transport in Delhi, India, respectively (Brandon \& Hommann, 1996; Sen, Tiwari, \& Upadhyay, 2010). Also, WHO recommends that a discount rate of $3 \%$ be applied to projects related to health and well-being taking into consideration the long length of time to produce benefits (WHO, 2003). In this sense, applying a low discount rate in the present research could be rational. Meanwhile, the cost-benefit analysis results in the present 
research are still preliminary and may need further examination. Thus, this line of research should be continued and extended in future. Third, the evaluation method that was performed in the present study on potential benefits of welfare packages needs to be tested for different socio-economic conditions. Furthermore, the same method may be applied to different sites in Bangladesh or other countries that face involuntary resettlement issues with different socio-economic backgrounds. Efforts for accumulating studies will be done in future research.

In conclusion, the present study proposes welfare packages to be implemented as part of comprehensive compensation packages for involuntary resettlement associated with infrastructure development projects. The present study shows that welfare packages in development-induced involuntary resettlement are economically viable and enhance satisfaction among affected people. It also shows that affected people indicate diverse attitudes toward the evaluation of merits expected from welfare packages depending on socio-demographic characteristics such as education, income, land, number of children, and land ownership, and perceptions of involuntary resettlement operations. This suggests that welfare packages contribute to enhancing quality of life and satisfaction among affected people in involuntary resettlement in the long run, and thus comprehensive compensation packages with welfare packages should be pursued for future development projects that involve involuntary resettlement.

\section{Acknowledgments}

This study was supported by the JDS Program funded by Japan International Cooperation Agency (JICA). The results of this study are not related to nor represent the opinions of the funding source or any government authorities.

\section{References}

ADB. (1998). Handbook on resettlement: A guide to good practice. Manila: ADB.

ADB. (2003). Report and recommendation of the president: Road Network Improvement and Maintenance Project II. Retrieved from http://www.adb.org/projects/documents/road-network-improvement-and-maintenance-project-ii-rrp

ADB. (2006). Involuntary resettlement safeguards. Retrieved from $\mathrm{http} / / / \mathrm{www} . \mathrm{adb}$. org/documents/involuntary-resettlement-safeguards

ADB. (2008a). Asian Development Bank's involuntary resettement safeguards: Project case studies in India (Vol. 2006). Retrieved from http://www.adb.org/documents/involuntary-resettlement-case-studies-india

ADB. (2008b). Asian Development Bank's involuntary resettlement safeguards: Project case studies in the $\begin{array}{llll}\text { Philippines } & \text { (Vol. 2006). } & \text { Retrieved }\end{array}$ http://www.adb.org/documents/involuntary-resettlement-case-studies-philippines

ADB. (2008c). Asian Development Bank's involuntary resettlement sefeguards: Project case studies in the People's Republic of China (Vol. 2006). Retrieved from http://www.adb.org/documents/involuntary-resettlement-case-studies-prc

ADB. (2013). Cost-benefit analysis for development: A practical guide. Manila: ADB.

ADB. (2014a). Bangladesh: Road Network Improvement and Maintenance Project II Completion Report. Retrieved from http://www.adb.org/projects/documents/road-network-improvement-and-maintenance-project-ii-pcr

ADB. (2014b). Road Network Improvement Maintenance Project II Overview: Project details. Retrieved November 24, 2014, from http://adb.org/projects/details?page=overview\&proj_id=34415-013

Barisal Correspondent. (2013, September 4). Move to acquire private land for marine academy protested. Dhaka Tribune. $\quad$ Retrieved $\quad$ November 24, 2014, from http://www.dhakatribune.com/law-amp-rights/2013/sep/03/move-acquire-private-land-marine-academy-pro tested

Brandon, C., \& Hommann, K. (1996). The cost of inaction: Valuing the economy-wide cost of environmental degradation in India (No. 9). UNU/IAS Working Paper. Tokyo: UNU.

Cernea, M. M. (1997). The risks and reconstruction model for resettling displaced populations. World Development, 25(10), 1569-1587. http://dx.doi.org/10.1016/S0305-750X(97)00054-5

Cernea, M. M. (Ed.). (1999a). The economics of involuntary resettlement: Questions and challenges. Washington, D.C.: World Bank Publications. http://dx.doi.org/10.1596/0-8213-3798-X 
Cernea, M. M. (1999b). Why economic analysis is essential to resettlement: A sociologist's view. Economic \& Policitical Weekly, 34(31), 2149-2158.

Cernea, M. M. (2003). For a new economics of resettlement: A sociological critique of the compensation principle. International Social Science Journal, 55(175), 37-45. http://dxdoi.org/10.1111/1468-2451.5501004

Dickinson, D., \& Webber, M. (2007). Environmental resettlement and development, on the steppes of Inner Mongolia, PRC. Journal of Development Studies, 43(3), 537-561. http://dx.doi.org/10.1080/00220380701204513

Dong, H., Kouyate, B., Cairns, J., Mugisha, F., \& Sauerborn, R. (2003). Willingness-to-pay for community-based insurance in Burkina Faso. Health Economics, 12(10), 849-862. http://dx.doi.org/10.1002/hec.771

Dong, H., Kouyate, B., Snow, R., Mugisha, F., \& Sauerborn, R. (2003). Gender's effect on willingness-to-pay for community-based insurance in Burkina Faso. Health Policy, 64(2), 153-162. http://dx.doi.org/10.1016/S0168-8510(02)00144-6

Dror, D. M., Radermacher, R., \& Koren, R. (2007). Willingness to pay for health insurance among rural and poor persons: Field evidence from seven micro health insurance units in India. Health Policy, 82(1), 12-27. http://dx.doi.org/10.1016/j.healthpol.2006.07.011

Fujikura, R., \& Nakayama, M. (2013). The long-term impacts of resettlement programmes resulting from dam construction projects in Indonesia, Japan, Laos, Sri Lanka and Turkey: A comparison of land-for-land and cash compensation schemes. International Journal of Water Resources Development, 29(1), 4-13. http://dx.doi.org/10.1080/07900627.2012.741032

Jalil, M. M. (2010). Approaches to measuring social discount rate: A Bangladesh perspective. SSRN Electronic Journal. Retrieved from http://dx.doi.org/10.2139/ssrn.1921987

Kaida, N., \& Dang, N. A. (2014). Economic valuation of the Nha Trang Bay Marine Protected Area: A willingness to pay survey on the conservation programs. Journal of Environmental Information Science, 24(5), 33-40.

Khatun, H. (2009). Displacement and poverty: Measures for restoring meagre livelihoods. In R. Modi (Ed.), Beyond relocation: The imperative of sustainable resettlement (pp. 331-353). New Delhi: SAGE Publications.

McDonald, B., Webber, M., \& Yuefang, D. (2008). Involuntary resettlement as an opportunity for development: The case of urban resettlers of the Three Gorges Project, China. Journal of Refugee Studies, 21(1), 82-102. http://dx.doi.org/10.1093/jrs/fem052

Ministry of Communications Roads and Highways Department. (2008). Bangladesh: Road Network Improvement and Maintenance Project II Resettlement Planning Document. Retrieved from http://www.adb.org/projects/documents/road-network-improvement-and-maintenance-project-ii-final-resettl ement-action-pla

Mitchell, R. C., \& Carson, R. T. (1989). Using surveys to value public goods: The contingent valuation method. Washington, D.C.: Resource for the Future.

Modi, R. (2009). Beyond relocation: The imperative of sustainable resettlement. New Delhi: SAGE Publications.

Momtaz, S., \& Kabir, S. M. Z. (2013). Evaluating environmental and social impact assessment in developing countries. Waltham: Elsevier.

Sen, A. K., Tiwari, G., \& Upadhyay, V. (2010). Estimating marginal external costs of transport in Delhi. Transport Policy, 17(1), 27-37. http://dx.doi.org/10.1016/j.tranpol.2009.09.003

Souksavath, B., \& Nakayama, M. (2013). Reconstruction of the livelihood of resettlers from the Nam Theun 2 hydropower project in Laos. International Journal of Water Resources Development, 29(1), 71-86. http://dx.doi.org/10.1080/07900627.2012.738792

Sunardi, Gunawan, B., Manatunge, J., \& Pratiwi, F. D. (2013). Livelihood status of resettlers affected by the Saguling Dam project, 25 years after inundation. International Journal of Water Resources Development, 29(1), 25-34. http://dx.doi.org/10.1080/07900627.2012.738593

Tilt, B., Braun, Y., \& He, D. (2009). Social impacts of large dam projects: A comparison of international case studies and implications for best practice. Journal of Environmental Management, 90 Suppl 3, S249-257. http://dx.doi.org/10.1016/j.jenvman.2008.07.030 
Webber, M., \& McDonald, B. (2004). Involuntary resettlement, production and income: Evidence from Xiaolangdi, PRC. World Development, 32(4), 673-690. http://dx.doi.org/10.1016/j.worlddev.2003.10.010

WHO. (2003). WHO guide to cost-effectiveness analysis. Geneva: WHO.

World Bank. (2001). Operation Policy (OP) 4.12: Involuntary resettlement. Retrieved from http://go.worldbank.org/GM0OEIY580

World Commision on Dams. (2000). Dams and development: A new framework for decision-making. London: Earthscan.

Zaman, M. Q. (1996). Development and displacement in Bangladesh: Toward a resettlement policy. Asian Survey, 36(7), 691-703.

Zhuang, J., Liang, Z., Lin, T., \& Guzman, F. De. (2007). Theory and practice in the choice of social discount rate for cost-benefit analysis: A survey (No. 94). Manila: ADB.

\section{Copyrights}

Copyright for this article is retained by the author(s), with first publication rights granted to the journal.

This is an open-access article distributed under the terms and conditions of the Creative Commons Attribution license (http://creativecommons.org/licenses/by/3.0/). 